\title{
Yields of Bell Pepper, Sweet Corn, and Peanut in Rotations
}

\author{
Vincent M. Russo \\ U.S. Department of Agriculture, Agricultural Research Service, South Central \\ Agricultural Research Laboratory, P.O. Box 159, Lane, OK 74555 \\ Additional index words. culture, vegetables, peanut marketable rating
}

\begin{abstract}
Abiotic and biotic factors, and government farm policy, affect peanut (Arachis hypogaea L.) production especially in the Southern Plains of the United States. A coincident increase in vegetable production has led to interest in diversification of production on land that has historically supported peanut. A multi-year experiment was conducted from 1998 to 2001 to determine how rotating bell pepper (Capsicum annuum var. annuum L.) and sweet corn (Zea mays L.) with peanut affect yields of all three crops. In the first year, the site was planted to peanut, except for those areas of the field that would have monocultured bell pepper or sweet corn throughout the experiment. In following years, parts of the field that were planted with peanut were planted with either peanut, bell pepper, or sweet corn. Except for the monocultured crops, plots had 2 years of peanut and one year each of bell pepper or sweet corn in one of four rotations. Yields were determined and terminal market value was assigned to crops. Cumulative yields for monocultured bell pepper and sweet corn were 27.8 and $22.8 \mathrm{Mg} \cdot \mathrm{ha}^{-1}$ after 4 years. The best yield of bell pepper or sweet corn in any rotation was 15.3 or $11.3 \mathrm{Mg} \cdot \mathrm{ha}^{-1}$, respectively. Rotation did not affect peanuts, and cumulative yields for monocultured peanut were $8.39 \mathrm{Mg}^{-h^{-1}}$ and averaged $2.13 \mathrm{Mg} \cdot \mathrm{ha}^{-1}$ per year in rotations. Cumulative yields for all crops in rotations where vegetables were planted in the last 2 years averaged $21.5 \mathrm{Mg} \cdot \mathrm{ha}^{-1}$ as opposed to 13.8 $\mathrm{Mg} \cdot \mathrm{ha}^{-1}$ when vegetables were planted in the middle 2 years of a 4 -year rotation. Yields of all crops were modified by environmental conditions, and terminal market price affected crop value so that high yields were not always associated with high returns.
\end{abstract}

Interest in rotating peanut (Arachis hypogaea L.) with other crops, and in diversifying production on peanut land in the Southern Plains of the United States, has increased because monoculture of peanut can lead to reduced yield (Akem et al., 1992; Bell and Sumner, 1984), and peanut are subject to changes in the national farm support system in the United States (Hoover and Sumner, 1985). In many peanut production areas in the United States, multiple cropping is possible (Sumner et al., 1978, 1979). Vegetables often have low yields following peanut as compared to following other vegetables (Sumner et al., 1983). In those trials, vegetables were planted in the same growing season as peanut. Russo (1997) determined that when bell pepper (Capsicum annuum var. annuum L.), dry bean (Phaseolus vulgaris L.) or cucumber (Cucumis sativus L.) followed by peanut in annual rotations, and the soil was covered with annual Italian ryegrass (Lolium multiflorum Lam.) during the overwintering period, vegetable yields declined over time. The best rotation sequence that will improve the yield of vegetables produced in rotation with peanut remains to be determined.

Received for publication 29 July 2002. Accepted for publication 15 Sept. 2003. Mention of a trademark, vendor, or proprietary product does not constitute a guarantee or warranty of the product by the USDA and does not imply its approval to the exclusion of other products that may also be suitable.
Brenneman et al. (1995) found that yields ofpeanut and Pensacola bahiagrass (Paspalum notatum Flüggé) were increased when they were grown in rotation. Since sweet corn (Zea mays L.) is also a monocot, with presumably some of the qualities that make other monocots a good component in rotations with peanut, it may be a viable addition to a rotation of peanut with other vegetables. Crop rotation will allow the diversification of land currently in peanut production, and provide producers with more flexibility. This experiment was designed to determine how yields of bell pepper, sweet corn, or peanut were affected by annual rotations as opposed to monoculture.

\section{Materials and Methods}

The experiment was conducted at Lane, Okla., on a Bernow fine-loamy, siliceous, thermic Glossic Paleudalf soil that was left fallow for a year prior to the first planting. In 1998, a 0.7-ha area was plowed, disced, and fertilizer with $112 \mathrm{~N}-180 \mathrm{P}-450 \mathrm{~K} \mathrm{~kg} \cdot \mathrm{ha}^{-1}$ was applied as a broadcast preplant. These amounts were based on results of soil tests to bring levels to those that would support vegetables (Motes and Roberts, 1994). The source of $\mathrm{N}$ was ammonium nitrate, $\mathrm{P}$ was phosphoric acid, and $\mathrm{K}$ was muriate of potash. This amount of the combined fertilizer was sufficient to support peanuts according to Oklahoma State Univ. recommendations (Sholar et al., 1996). Russo (1991) found that a single preplant application of a combined N-P-K fertilizer was sufficient to produce acceptable yields for bell pepper. Beds on 0.9 m centers were constructed in each year with a rolling cultivator and were $\approx 25$ $\mathrm{cm}$ high and $8 \mathrm{~cm}$ across at the rounded top. The entire area, with the exception of those plots that would be planted to monocultures of bell pepper or sweet corn, was planted with 'Spanco' peanut.

In the years following 1998, the area planted initially to peanut was subdivided into plots, each of which was assigned to either one of four rotations, or a monoculture check which was planted to bell pepper, or sweet corn or peanut (Table 1). Each plot was $9.1 \mathrm{~m}$ wide $\times 23 \mathrm{~m}$ long, with 10 treatment rows oriented east to west. Guard rows of either peanut or vegetables were on the north and south sides of plots.

Plots were planted with either 6-week-old greenhouse grown seedlings of 'Bell Captain' bell pepper using a vegetable transplanter (Holland Transplant Co., Holland, Mich.), or direct seeded with 'Summer Sweet 7630Y' sweet corn, or 'Spanco' peanut, both of which were planted with a vacuum planter (Monosem NG, ATL, Lenexa, Kans.). In-row spacing was $46 \mathrm{~cm}$ for bell peppers, $23 \mathrm{~cm}$ for sweet corn, and $6.4 \mathrm{~cm}$ for peanut. The experimental design was a randomized complete block with combinations of rotations (4) and monoculture (3) making up the whole plot treatments within blocks which were replicated four times in each year.

The herbicide $\alpha, \alpha, \alpha$-trifluoro-2,6-dinitro$\mathrm{N}, \mathrm{N}$-dipropyl- $\rho$-toluidine (trifluralin) was applied preplant to soil that was to be planted to bell pepper and peanut, and 2-chloro-N(2-ethyl-6-methylphenyl- $N$-(2-methoxy-1methylethyl) acetamide (metolachlor) was applied post emergence to soil which was to be planted with sweet corn to control weeds. Sweet corn was treated with a Bacillus thuringiensis-containing insecticide at the first sign of silk elongation, and additionally at 5 dintervals until silks were brown. Tetrachloroisophthalonitrile (chlorothalonil) was applied when symptoms of fungal colonization were observed on peanut foliage, and alternated with

Table 1. Sequence of peanut and bell pepper and sweet corn in annual rotations at Lane, Okla., from 1998 to 2001.

\begin{tabular}{lcccc}
\hline & \multicolumn{4}{c}{ Year } \\
\cline { 2 - 5 } Planting strategy & 1998 & 1999 & 2000 & 2001 \\
\hline Monoculture bell pepper & $\mathrm{BP}^{\mathrm{z}}$ & $\mathrm{BP}$ & $\mathrm{BP}$ & $\mathrm{BP}$ \\
Monoculture sweet corn & $\mathrm{SC}$ & $\mathrm{SC}$ & $\mathrm{SC}$ & $\mathrm{SC}$ \\
Monoculture peanut & $\mathrm{P}$ & $\mathrm{P}$ & $\mathrm{P}$ & $\mathrm{P}$ \\
Rotation 1 & $\mathrm{P}$ & $\mathrm{P}$ & $\mathrm{SC}$ & $\mathrm{BP}$ \\
Rotation 2 & $\mathrm{P}$ & $\mathrm{P}$ & $\mathrm{BP}$ & $\mathrm{SC}$ \\
Rotation 3 & $\mathrm{P}$ & $\mathrm{SC}$ & $\mathrm{BP}$ & $\mathrm{P}$ \\
Rotation 4 & $\mathrm{P}$ & $\mathrm{BP}$ & $\mathrm{SC}$ & $\mathrm{P}$ \\
\hline zabbreviations: $\mathrm{BP}=$ bell pepper; $\mathrm{P}=$ peanut; and SC = sweet corn
\end{tabular}

HortScience, Vol. 38(7), December 2003 
$N$-(2,6-dimethyl-phenyl)- $N$-(meth-oxyacetyl alanine (metalaxyl), in weekly applications. There was not sufficient pressure from insects or disease to apply pesticides to bell pepper. In September of each year, annual Italian ryegrass was planted as an overwintering cover crop at $30 \mathrm{~kg} \cdot \mathrm{ha}^{-1}$ in each plot without additional fertilization.

Bell pepper and sweet corn were harvested and yields determined when they reached grade US\#1 or better [U.S. Dept. of Agriculture (USDA), 1989, 1992]. Bell peppers were harvested three times over $14 \mathrm{~d}$. Sweet corn was harvested once. Numbers and weight of marketable bell pepper fruit and sweet corn ears were determined. Peanuts were mechanically harvested once, dried, and graded according to USDA Food Safety and Inspection Service standards. The percent of sound mature kernels (SMK) of peanut yield samples was determined. Removal of peanut hay from the field for cattle feed is a common practice in the region. Peanut hay was removed from the field in each year, except for 1998, when heavy rains occurring after harvest of peanuts made removal of peanut hay impossible.

Total precipitation for the growing period, average high and low air temperatures and their ranges, number of nights with temperatures $\geq 22^{\circ} \mathrm{C}$, and number of days with temperatures $\geq 38^{\circ} \mathrm{C}$, and days to first harvest for each crop were tabulated (Table 2). Yields for bell pepper or sweet corn only, the combined yields for bell pepper and sweet corn, the yield for peanut only, and cumulative yields of all crops in rotations, as well as the SMK rating for peanut were determined.

Terminal market prices for vegetables at the Dallas market were determined for periods during which harvests occurred. Terminal market prices are reported by the USDA, ARS, Agricultural Marketing Service as ranges based on number and quality of products. Prices for bell pepper and sweet corn were averages of terminal market prices during the harvest period for each crop. Peanut value was based on the support price for peanut which represents the price for an "average rating" based on yield and SMK rating. Data were analyzed by the general linear models procedures in SAS (SAS Institute, 2001). Where appropriate, data were subjected to the Ryan-Einot-Gabriel-Welsch $\mathrm{F}$ test for post hoc means separation.

\section{Results}

The years 1998 to 2001 varied in weather conditions (Table 2). Days to harvest in 1998 to 2001 were different for all crops in rotations. Total precipitation was highest in peanut in 1999 and 2001 and for bell pepper and sweet corn in 1999. For peanut the number of nights with temperatures $\geq 22$ ${ }^{\circ} \mathrm{C}$ during the growing seasons decreased from 1998 to 2001 and there were fewer days with temperatures $\geq 38{ }^{\circ} \mathrm{C}$ in 1999 and 2000 than in 1998 and 2001. For bell pepper the number of nights with temperatures $\geq 22$ ${ }^{\circ} \mathrm{C}$ was highest during the 2000 growing season, and for sweet corn the number of nights with temperatures $\geq 22^{\circ} \mathrm{C}$ was least in 2001. There were few days with temperatures $\geq 38{ }^{\circ} \mathrm{C}$ for the bell pepper and sweet corn growing seasons.

Distribution of yields and terminal market prices for each crop within the plantings are presented in Table 3 . The cumulative terminal market prices for rotation 1 and 2 were both less than for monocultured bell pepper, and for rotation 2 less than for monocultured bell pepper and sweet corn. Rotation 3 had the lowest total market value. Rotation 4, which had less cumulative yield than other rotations, had a total market value similar to that for rotation 2. This was due to the confluence of yield and value of bell pepper.

Analysis of variance indicated that rotation affected yields of individual vegetables, combined yields for bell pepper and sweet corn, and cumulative yields for all crops in rotations and for crops in monoculture (Table 4). Peanut yield and SMK rating were not affected by planting strategy (rotation vs. monoculture) and averaged $2.13 \mathrm{Mg} \cdot \mathrm{ha}^{-1}$ and $66.5 \%$, respectively. Cumulative peanut yield in monoculture was $8.39 \mathrm{Mg} \cdot \mathrm{ha}^{-1}$. In rotation, the yield for bell pepper was highest for rotation 1 followed by rotation 4 , and for sweet corn, yield was highest for rotation 2 . The combined yields for bell pepper and sweet corn in rotation, and the total cumulative yield of all crops (bell pepper, sweet corn and peanuts) in rotation, were highest in rotation 1 and 2 followed by rotation 4 . The monoculture of bell pepper and sweet corn produced cumulative yields that were similar to cumulative yields for the best rotations.

\section{Discussion}

In multiple year rotations, or monoculture over several years, expression of plant development and yields are in part, the result of the influences of biotic and abiotic factors. Monoculture can bring about changes in soil $\mathrm{pH}$ and tilth, residual nutrients, and in populations of disease and beneficial organisms (Shippers et al., 1987; Shipton, 1977). In some cases, rotation of crops can be used to improve yield of some or all crops in a rotation (Curl, 1963; Russo, 1997; Sumner, 1984). Rotation affected yield, and results appeared to be modified by environmental conditions.

Vegetable (Pierce, 1987) and peanut (Bagnall and King, 1991) flower production and retention can be adversely affected by air temperature. The occasionally higher marketable yields for bell pepper and sweet corn are likely explained by the coincidence by the year in the rotation and conducive weather. For bell pepper, Rylski (1973) determined that temperature affected fruit development, and for some time it has been known that high night temperatures were detrimental to flower and fruit retention (Cochran, 1932; Deli and Tiessen, 1969). It is likely that it is the time in the plant's development that the high night temperatures occur, rather than the number of nights with high temperatures, that effect fruit development in pepper. Since high night temperatures likely did not occur when most pepper flowers and fruit were being formed, the damage to yield was minimized. It may also be that higher night temperatures occurring during fruit filling might be beneficial to yield if adequate water is provided to plants. For peanut the number of nights with temperatures $\geq 22{ }^{\circ} \mathrm{C}$ may have affected yield, and would be in agreement with Bagnall and King (1991) who reported that high night temperatures are detrimental to peanut flower production and retention.

Cumulative yields for vegetables in rotations 1 and 2 were among the highest. The capacity to produce high yields under conducive environmental conditions allowed bell pepper and sweet corn to contribute to higher cumulative yields. Peanut in the rotations yielded at a consistent rate. Increases in cumulative yields in the rotations were due to contributions of bell pepper and sweet corn rather than

Table 2. Planting and last harvest dates and days to harvest for peanut, bell pepper, and sweet corn planted in rotation from 1998 to 2001 at Lane, Okla.

\begin{tabular}{|c|c|c|c|c|c|c|c|c|c|c|c|}
\hline \multirow[b]{3}{*}{ Crop } & \multirow[b]{3}{*}{ Year } & \multirow{2}{*}{\multicolumn{2}{|c|}{ Date }} & \multirow{3}{*}{$\begin{array}{l}\text { Days to } \\
\text { first harvest }\end{array}$} & \multirow{3}{*}{$\begin{array}{c}\text { Total } \\
\text { precip. } \\
(\mathrm{cm})\end{array}$} & \multicolumn{4}{|c|}{ Temp $\left({ }^{\circ} \mathrm{C}\right)$ between planting and last harvest } & \multirow{3}{*}{$\begin{array}{c}\text { Nights at } \\
22^{\circ} \mathrm{C}\end{array}$} & \multirow{3}{*}{$\begin{array}{l}\text { Days at } \\
\text { at } 38^{\circ} \mathrm{C}\end{array}$} \\
\hline & & & & & & & iimum & & imum & & \\
\hline & & Planting & Last harvest & & & $\overline{\text { Avg. }}$ & Range & Avg. & Range & & \\
\hline \multirow[t]{4}{*}{ Peanut } & 1998 & 21 Apr. & 1 Oct. & 163 & 28.07 & 19 & $4-28$ & 32 & $16-43$ & 100 & 42 \\
\hline & 1999 & 17 May & 7 Oct. & 143 & 64.34 & 18 & $4-24$ & 31 & $21-41$ & 62 & 12 \\
\hline & 2000 & 26 May & 9 Sept. & 106 & 20.47 & 20 & $14-24$ & 34 & $24-43$ & 48 & 28 \\
\hline & 2001 & 2 May & 24 Sept. & 145 & 69.09 & 18 & $7-24$ & 32 & $18-32$ & 5 & 40 \\
\hline \multirow[t]{4}{*}{ Bell pepper } & 1998 & 14 Apr. & 25 June & 72 & 14.55 & 16 & $3-26$ & 28 & $13-37$ & 6 & 0 \\
\hline & 1999 & 19 Apr. & 16 June & 59 & 40.92 & 16 & $0-23$ & 27 & $14-32$ & 8 & 0 \\
\hline & 2000 & 18 Apr. & 20 June & 62 & 16.69 & 17 & $4-24$ & 28 & $18-34$ & 27 & 0 \\
\hline & 2001 & 16 Apr. & 21 June & 65 & 7.21 & 15 & $4-24$ & 29 & $15-33$ & 7 & 0 \\
\hline \multirow{4}{*}{ Sweet corn } & 1998 & 13 Apr. & 2 July & 80 & 14.76 & 17 & $3-25$ & 31 & $16-38$ & 26 & 1 \\
\hline & 1999 & 3 May & 14 July & 73 & 50.83 & 19 & $8-24$ & 29 & $23-33$ & 24 & 0 \\
\hline & 2000 & 20 Apr. & 10 July & 81 & 16.69 & 17 & $4-24$ & 28 & $18-34$ & 25 & 0 \\
\hline & 2001 & 20 Apr. & 5 July & 77 & 14.33 & 17 & $4-22$ & 29 & $23-33$ & 10 & 0 \\
\hline
\end{tabular}


Table 3. Yields and terminal market prices of bell pepper, sweet corn, and peanuts in rotation and monoculture at Lane, Okla., from 1998 to 2001

\begin{tabular}{|c|c|c|c|c|c|c|c|c|c|}
\hline \multirow[b]{2}{*}{ Planting strategy } & \multicolumn{4}{|c|}{ Yields in year } & \multicolumn{5}{|c|}{ Terminal market prices by year and total } \\
\hline & 1998 & 1999 & 2000 & 2001 & 1998 & 1999 & 2000 & 2001 & Total \\
\hline Monoculture bell pepper & $0.74^{2}$ & 8.65 & 4.61 & 13.75 & $1,075^{y}$ & 10,237 & 4,816 & 14,354 & 30,482 \\
\hline ulture sweet corn & 6.07 & 2.68 & 2.50 & 11.55 & 7,916 & 1,075 & 1,631 & 9,542 & 20,164 \\
\hline Mon & 1.72 & 1.76 & 2.91 & 2.00 & 1,048 & 1,073 & 1,774 & 1,163 & 5,058 \\
\hline Rota & $1.61 \mathrm{P}$ & $2.20 \mathrm{P}$ & $3.10 \mathrm{SC}$ & 15.33 & 981 & 1,344 & 1,452 & 19,779 & 23,556 \\
\hline & $1.90 \mathrm{P}$ & $2.80 \mathrm{P}$ & $4.69 \mathrm{BP}$ & $11.26 \mathrm{SC}$ & 1,158 & 1,707 & 4,980 & 8,971 & 16,816 \\
\hline Rot & $1.96 \mathrm{P}$ & $2.03 \mathrm{SC}$ & $4.85 \mathrm{BP}$ & $2.48 \mathrm{P}$ & 1,194 & 1,586 & 5,152 & 1,440 & 8,372 \\
\hline Rotation 4 & $1.46 \mathrm{P}$ & $10.42 \mathrm{BP}$ & $1.79 \mathrm{SC}$ & $2.61 \mathrm{P}$ & 1,996 & 12,342 & 842 & 1,512 & 16,692 \\
\hline
\end{tabular}

${ }^{\mathrm{z}} \mathrm{Mg} \cdot \mathrm{ha}^{-1}$ of peanut $(\mathrm{P})$, sweet corn (SC), and bell pepper (BP).

yPrices in U.S. dollars per hectare, rounded to the nearest whole dollar during the periods of harvest for each crop in each year. Average prices for BP were: $\$ 17.20, \$ 16.60, \$ 14.63$, and $\$ 14.63$ per $61.6 \mathrm{~kg}$ case in $1998,1999,2000$, and 2001, respectively. Average prices for SC were $\$ 15, \$ 8, \$ 9$, and $\$ 15$ per 4 doz ears in 1998, 1999, 2000 and 2001, respectively. Farm support prices for P were: \$1366, \$1366, \$1366, and $\$ 1304$ in $1998,1999,2000$, and 2001 per $\mathrm{Mg}$, respectively.

Table 4. Effect of rotation on bell pepper and sweet corn yield, combined yields of bell pepper and sweet corn in rotations, cumulative yields of all crops in rotations, and yields of monocultured vegetables or peanut at Lane, Okla., from 1998 to 2001.

\begin{tabular}{|c|c|c|c|c|}
\hline \multirow[b]{2}{*}{ Planting stategy } & \multicolumn{2}{|c|}{ Individual crop $^{z}$} & \multicolumn{2}{|l|}{ Avg yield } \\
\hline & $\begin{array}{c}\text { Bell } \\
\text { pepper }\end{array}$ & $\begin{array}{c}\text { Sweet } \\
\text { corn }\end{array}$ & $\begin{array}{l}\text { Combined bell pepper } \\
+ \text { sweet corn }\end{array}$ & $\begin{array}{l}\text { Cumulative } \\
\text { all crops }\end{array}$ \\
\hline & ------- & & $\left(\mathrm{Mg} \cdot \mathrm{ha}^{-1}\right)---$ & ----------- \\
\hline Monoculture bell pepper & --- & --- & --- & $27.75 \mathrm{a}$ \\
\hline Monoculture sweet corn & --- & --- & --- & $22.80 \mathrm{a}$ \\
\hline Monoculture peanut & --- & --- & --- & $8.39 \mathrm{~d}$ \\
\hline Rotation 1 & $15.33 \mathrm{a}^{\mathrm{y}}$ & $3.10 \mathrm{~b}$ & $18.43 \mathrm{a}$ & $22.24 \mathrm{a}$ \\
\hline Rotation 2 & $4.69 \mathrm{c}$ & $11.26 \mathrm{a}$ & $15.95 \mathrm{a}$ & $20.65 \mathrm{a}$ \\
\hline Rotation 3 & $4.85 \mathrm{c}$ & $2.03 \mathrm{~b}$ & $6.88 \mathrm{c}$ & $11.32 \mathrm{c}$ \\
\hline Rotation 4 & $10.42 \mathrm{~b}$ & $1.79 \mathrm{~b}$ & $12.21 \mathrm{~b}$ & $16.28 \mathrm{~b}$ \\
\hline
\end{tabular}

${ }^{2}$ Bell pepper and sweet corn were grown in only 1 year each of the 4 years in the rotations. y Values in a column followed by the same letter are not significantly different at $P \leq 0.05$, Ryan-Einot-Gabriel-Welsch multiple F test. "---" value not measured or not presented in a column.

peanut. This was true for bell pepper or sweet corn in the fourth year of the rotation 1 and 2. However, that may have been due to the weather conditions, since yields of bell pepper and sweet corn in monoculture in that same year were also high.

It appears that monoculture of pepper and sweet corn for up to 4 years at this location is not detrimental to yield, suggesting that pressure from disease organisms was not a major concern. Russo (1997) found that in other rotations with peanut that the population of sclerotia of soilborne fungi was not related to yields of pepper following peanut. Historically there has been little pressure from insects and disease affecting yield of bell pepper at this location. Although monoculture of the vegetables produced some of the best yields it may be that biotic factors leading to stress on the plant might build up over a longer period than that tested.

Perennial Italian ryegrass (L. perenne L.) can interfere, principally through density, with yield of some vegetables (Bell, 1995). It did not appear that annual Italian ryegrass caused a problem due to allelopathy or any other mechanism. That the peanut hay was not removed after the 1998 harvest did not appear to create problems since peanut yields in 1999 in those same plots were generally unchanged. It is difficult to make a judgement concerning the effect of incorporated peanut residue on the vegetables that followed in the next growing season since this occurrence was unplanned and there was no control for comparison.

The expected yield for crops, and their expected value as returns to the producer, are factors on which production decisions are made. Sumner (1994) stated that use of some crops in rotations may not be profitable due, in part, to economic factors. In all cases, vegetable production returned greater value than monoculture peanut. The valuation of crops in rotation 1 were similar to those of monocultured vegetables. However, some of this valuation was due to support prices for peanut. The support price for peanut was reduced to $\$ 720 / \mathrm{Mg}$ in 2002 and when set Fall 2003 is projected to be unchanged or lower. It appears that peanut producers should consider the use of rotation with vegetables. The use of rotations can lead to diversification that is key to the goal of attaining sustainable production.

\section{Literature Cited}

Akem, C.N., H.A. Melouk, and O.D. Smith. 1992. Field evaluation of peanut genotypes for resistance to Sclerotinia blight. Crop Protect. 11: 345-348.

Bagnall, D.J. and R.W. King. 1991. Response of peanut (Arachis hypogaea) to temperature, photoperiod and irradiance. 2. Effect on peg and pod development. Field Crops Res. 26: 279--283.

Bell, C.E. 1995. Broccoli (Brassica oleracea var botrytis) yield loss from Italian ryegrass (Lolium penenne) interference. Weed Sci. 43:117-120.

Bell, D.K. and D.R. Sumner. 1984. Unharvested peanut pods as a potential source for inoculum of soilborne plant pathogens. Plant Dis. 68: 1038-1042.

Brenneman, T.B., D.R. Sumner, R.E. Baird, G.W. Burton, and N.A. Minton. 1995. Suppression of foliar and soilborne peanut diseases in bahiagrass rotations. Phytopathology 85:948-952.

Cochran, H.L. 1932. Factors affecting flowering and fruit setting in the pepper. Proc. Amer. Soc. Hort. Sci. 29:434-437.

Curl, E.A. 1963. Control of plant diseases by crop rotation. Bot. Rev. 29:413-479.

Deli, J. and H. Tiessen. 1969. Interaction of temperature and light intensity on flowering of Capsicum frutescens var. grossum cv. California Wonder. J. Amer. Soc. Hort. Sci. 40:493-497.

Hoover, D.M. and D.A. Sumner. 1985. Tobacco and peanut, p. 123-138. In:H.E. Pattee and C. Young (eds.). Alternative agricultural and food policies and the 1985 farm bill. Giannini Foundation of Agr. Econ., Univ. Calif., Berkeley.

Motes, J.E. and W. Roberts. 1994. Fertilizing commercial vegetables. OSU Extension Facts. No. 6000. Oklahoma State Univ., Stillwater.

Pierce, L.C. 1987. Vegetables: Characteristics, production and marketing. Wiley, New York.

Russo, V.M. 1991. Effects of fertilizer rate, application timing and plant spacing on yield and nutrient content of bell pepper. J. Plant Nutr. 14:1047-1056.

Russo, V. M. 1997. Yields of vegetables and peanut in rotation plantings. HortScience 32:209-212.

Rylski, I. 1973. Effect of night temperature on shape and size of sweet pepper (Capsicum аппиит L.). J. Amer. Soc. Hort. Sci. 98:149-152.

SAS Institute. 2001. SAS/STAT user's guide, Version 8.2. SAS Inst., Cary, N.C.

Shippers, B., A.W. Bakker, and P.A. Bakker. 1987. Interactions of deleterious and beneficial microorganisms and the effect of croping practices. Annu. Rev. Phytopathol. 25:339-358.

Shipton, P.J. 1977. Monoculture and soilborne plant pathogens. Annu. Rev. Phytopathol. 15: 387-407.

Sholar, R., J. Damicone, M. Kizer, R. Noyes, G. Johnson, and P. Mulder. 1996. Peanut production guide for Oklahoma. Okla. Coop. Ext. Serv. Circ. E-608, Oklahoma State Univ., Stillwater.

Sumner, D.R. 1984. Cropping practices and roo disease, p. 267-270. In:C.A.Parker,A.D. Rovira, J.J. Moore, P.T.W. Wong, and J.F. Kollmogen (eds.). Ecology and management of soilborne plant pathogens. Amer. Phytopathol. Soc., St. Paul, Minn.

Sumner, D.R. 1994. Approaches to cultural management, p. 309-333. In: C.L. Campbell and D.M Benor (eds.). Epidemiology and management of root diseases. Springer-Verlag, New York.

Sumner, D.R., A.W. Johnson, N.C. Glaze, and C.C. Dowler. 1978. Root diseases of snapbean and southern pea in intensive cropping systems. Phytopathology 68:955-961.

Sumner, D.R., N.C. Glaze, C.C. Dowler, and A.W. Johnson. 1979. Herbicide treatments and root diseases of turnip in intensive cropping systems. Plant Dis. Rptr. 63:801-805.

Sumner, D.R., C.C. Dowler, A.W. Johnson, N.C. Glaze, S.C. Phatak, R.B. Chalfant, and J.E. Epperson. 1983. Root diseases in cucumber in irrigated multiple-cropping system with pest management. Plant Dis. 67:1071-1075.

U.S. Department of Agriculture. 1989. United States standards for grades of sweet peppers. Agr. Market. Serv., Washington, D.C.

U.S. Department of Agriculture. 1992. United States standards for grades of sweet corn. Agr. Market. Serv., Washington, D.C. 